\title{
GEZICHTSPUNT
}

\section{Alternatieve geneeswijzen in de Wet BIG: meer toezicht doet wonderen?}

Niet alle nieuwe wetgeving betekent vooruitgang. De Wet BIG is daarvan een voorbeeld. Het niet meer beschermen tegen de onbevoegde uitoefening van geneeskunst en het beperken van de werkingssfeer van het tuchtrecht voor artsen/managers ${ }^{\mathrm{I}}$ geven de nodige discussie. Hier ga ik op het eerste punt in.

Naar aanleiding van de casus S.M. heeft de Minister van VWS in september 2004 de Raad voor de Volksgezondheid en Zorg (RVZ) gevraagd een advies uit te brengen over de vraag of de medische diagnose als voorbehouden handeling in de Wet BIG moet worden opgenomen. Neen, zegt de RVZ in zijn advies van april 2005, en adviseert vervolgens tot meer en betere voorlichting aan patiënten. Indien toch wettelijke maatregelen nodig zijn, zo zegt de RVZ, dan moet het afwijken van de diagnose, behandeling of prognose van een arts door een niet-arts als voorbehouden handeling worden aangemerkt. De nu lopende discussie is een aardig voorbeeld van de dilemma's in gezondheidszorgwetgeving tussen zelfbeschikking en bescherming. Het lijkt erop dat er de laatste tijd steeds meer stemmen opgaan vóór meer bescherming, toezicht en controle. Mede om die reden is dit jaar ook de reikwijdte van de Kwaliteitswet zorginstellingen uitgebreid (Stb. 2005, 63). Mijns inziens terecht.

Zou echter, in plaats van de voorbehouden handelingen uit te breiden, uitbreiding van artikel 40 van de Wet BIG tot alle individuele beroepsbeoefenaren niet een veel voor de hand liggender weg zijn als men de patiënt wil beschermen? Een belangrijk deel van de Wet BIG is immers ook van toepassing op niet-geregistreerde beroepsbeoefenaren op het gebied van de individuele gezondheidszorg (zie bijv. art. 88 Wet $\mathrm{BIG}$. Het instrumentarium van artikel 40 Wet BIG geeft de minister fijnmazige mogelijkheden om zo nodig tot nadere regulering te komen, indien gewenst met een strafrechtelijke sanctie. Bovendien, niemand zal betwisten dat ook alternatieve genezers verantwoorde zorg dienen te leveren. Wat is er derhalve op tegen om dit in de wet vast te leggen? ${ }^{2}$ Een dergelijke bepaling past mijns inziens beter in het in de Wet BIG gekozen stelsel dan een uitbreiding van de voorbehouden handelingen.

Het van toepassing verklaren van artikel 40 geeft bovendien de Inspectie de mogelijkheid om, indien dat noodzakelijk is, een bevel ex artikel 87 a van de Wet BIG te geven. Handhaving is dan niet alleen afhankelijk van eventueel strafrechtelijk optreden, hetgeen een voordeel is gezien de overbelasting en gebrek aan deskundigheid bij het openbaar ministerie.

Dus niet verketteren of omarmen, maar wel toezicht houden en controleren.

\section{W.R. Kastelein}

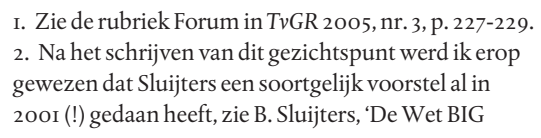

I. Zie de rubriek Forum in TvGR 2005, nr. 3, p. 227-229. 2. Na het schrijven van dit gezichtspunt werd ik erop gewezen dat Sluijters een soortgelijk voorstel al in 200 (!) gedaan heeft, zie B. Sluijters, 'De Wet BIG

tegen het licht: betere bescherming en nog wat', TvGR 200I, p. 29-36. De RVZ heeft dit artikel naar het zich laat aanzien helaas niet bij zijn rapport betrokken. 